Article

\title{
Paint Pull-Off Strength and Permeability in Nanosilver-Impregnated and Heat-Treated Beech Wood
}

\author{
Hamid Taghiyari 1,*, Ayoub Esmailpour ${ }^{2}$ and Antonios Papadopoulos ${ }^{3, * \mathbb{D}}$ \\ 1 Wood Science and Technology Department, Faculty of Materials Engineering \& New Technologies, \\ Shahid Rajaee Teacher Training University, Tehran 14115, Iran \\ 2 Department of Physics, Faculty of Sciences, Shahid Rajaee Teacher Training University, Tehran 14115, Iran; \\ esmailpour@sru.ac.ir \\ 3 Laboratory of Wood Chemistry and Technology, Department of Forestry and Natural Environment, \\ International Hellenic University, GR-6 600 Drama, Greece \\ * Correspondence: htaghiyari@sru.ac.ir (H.T.); antpap@teiemt.gr (A.P.)
}

Received: 7 October 2019; Accepted: 30 October 2019; Published: 1 November 2019

\begin{abstract}
The effects of impregnation with nanosilver suspension as well as heat treatment on pull-off adhesion strength and specific air permeability in beech specimens were studied here. The size range of silver nanoparticles was $30-80 \mathrm{~nm}$. The cross-section of specimens was cold-sprayed with unpigmented sealer-clear, polyester, and lacquer paints. Heat treatment, as the most commonly used wood modification, was applied at three different temperatures of 145,165 , and $185{ }^{\circ} \mathrm{C}$. Results showed that the highest and lowest pull-off strengths were found in the un-impregnated and unheated specimens painted with polyester $(8.98 \mathrm{MPa})$ and the unpainted unheated nanosilver-impregnated specimens (3.10 MPa), respectively. Impregnation with nanosilver resulted in the rupture of perforation plates and pit openings, and eventually, permeability increased significantly. As for the pull-off adhesion strength, the increased permeability resulted in the adhesive being penetrated in to the pores in the wood substrate, and eventually, a significant decrease in the pull-off strengths occurred. No significant correlation was found between pull-off strength versus specific air permeability, although both properties depend on the porous structure. This was due to the fact that permeability depends on the continuous pore system, while pull-off strength is dependent on the surface pore system of the substrate.
\end{abstract}

Keywords: coating; modification; nanotechnology; un-pigmented paints; permeability; pull-off

\section{Introduction}

As solid woods are natural porous media, many of their properties depend on the size of the pores, the way they are interconnected or isolated from the neighboring pores, and even the quality of the surface of the pores [1-4]. Many factors influence the formation of wood and its structure and porous system thereof-factors such as initial spacing, intercropping with different plants, drying procedures [5-7], growing season, extractive content, moisture content, and hygroscopicity of wood [8,9]. Therefore, researchers constantly look for new methods to modify wood for better mechanical properties because few species offer radial and axial uniformity in their produced wood [10].

Thermal modification is generally considered the most commercially-used wood modification method [11]. It has been recognized as a method to improve the dimensional stabilization of wood and increase its decay resistance [11-13]. Thermal modification at high temperatures has decreasing effects on some mechanical properties of wood. However, there are some ways to mitigate the decreasing results [14]. Thermal modification is mostly carried out between the temperatures of 
160 and $260{ }^{\circ} \mathrm{C}$. Temperatures that are lower than $140{ }^{\circ} \mathrm{C}$ usually result in very little changes in the mechanical properties, but higher temperatures result in so much degradation that the mechanical properties are usually unacceptable. Thermal modification processes that are currently used at an industrial scale are not higher than $260^{\circ} \mathrm{C}$; in practice, temperatures between 150 and $230^{\circ} \mathrm{C}$ are more accepted [11,15]. The reduction of swelling in wood specimens caused by increase in temperature and duration of heat treatment was often attributed to the destruction in hemicellulose compounds [15]. However, structural modifications and chemical changes of lignin were suggested to also be involved in the process [15]. Moreover, Borrega and Kärenlampi [8] revealed that a reduction in hygroscopicity can not only be attributed to mass loss, but another mechanism that was also active in the process. They suggested that the active mechanism might be an irreversible hydrogen bonding that occurs during the process of water movement within the porous system of wood structures. This bonding was reported by other researchers to change physical and mechanical properties, as well as fluid flow in the solid woods.

High thermal conductivity coefficients of metal nanoparticles [16-20] were used in improving some of the properties in solid woods and wood-composite materials [21]. Impregnation with nanosilver suspension as well as heat treatment were also reported to alter the porous structure of solid woods, significantly altering the gas and liquid permeability [22], and possibly the penetration of paints in to the porous structure, eventually changing the adhesion strength of paints. However, authors found no or little literature on the effects of impregnation with metal nanosuspension and thermal treatment on the correlation between the paint pull-off adhesion strength with permeability in solid woods. Therefore, the present study was carried out to firstly find out the effects of nanosilver-impregnation and heat treatment on the gas permeability of beech wood, as a commercial wood species. Thereafter, and as to the nondestructive nature of permeability measurement process, pull-off strength was measured in the same specimens, providing the possibility to find out the effects of nanosilver-impregnation and heat treatment on this property, too. With regard to the fact that both of these properties, permeability and pull-off strength, depend in some way on the porous structure of the substrate, correlation between them was calculated. Moreover, as to the low thermal conductivity coefficient of wood, a separate set of specimens was impregnated with nanosilver suspension to increase thermal conductivity in the specimens and decrease the heat treatment gradient in them. This can also accelerate thermal treatment.

\section{Materials and Methods}

\subsection{Specimen Procurement}

Five discs from different beech trees (Fagus orientalis Lipsky) were cut at breast-height and air dried. From each disk, 80 longitudinal cylindrical specimens were prepared. The diameter of specimens was $17 \mathrm{~mm}$, and the length was $30 \mathrm{~mm}$. Specimens were checked not to have any knots, fissures, or cracks. They were first air dried for eight months, and then they were kept for four weeks in a conditioning room $\left(25 \pm 2{ }^{\circ} \mathrm{C}\right.$, and $40 \% \pm 3 \%$ relative humidity) to avoid any undesirable effects of kiln-drying [23]. Specimens were divided into two equal groups of control (C) and nanosilver-impregnated (NS) groups. Each group was again divided into four subgroups of unheated, heat-treated at $145^{\circ} \mathrm{C}$ (HT-145), heat-treated at $165^{\circ} \mathrm{C}$ (HT-165), and heat-treated at $185^{\circ} \mathrm{C}$ (HT-185). Gas permeability of all specimens was measured in the first phase of the research project before any heat treatment and impregnation. The NS specimens were then impregnated with a $400 \mathrm{ppm}$ aqueous nanosilver suspension. All specimens were again kept in a conditioning room for two more months. Gas permeability was again measured. They were painted with three unpigmented resins of sealer-clear, polyester, and lacquer with organic solvent, produced by Pars-Eshen Co., as to their great popularity in the local market. A dolly was stuck to one end of the specimens for the paint-adhesion testing. Moisture content of specimens was $8 \% \pm 0.5 \%$ in all treatments when permeability and pull-off tests were carried out because wood has a thermo-hygromechanical behavior and the properties relating to its deformation depend on the same factors, including moisture content, temperature, and relative humidity [24]. 


\subsection{Pull-Off Adhesion Strength Testing}

Adhesion strength testing provides the force needed to pull a test diameter of coating away from the substrate. Adhesion tests were carried out in accordance with ASTM D4541-02 [25]. In the present study, an automatic PosiTest ${ }^{\circledR}$ pull-off adhesion tester (DelFesko, NY, USA) was used (Figure 1). This was a self-aligning spherical dolly-head tester (Type V according to the ASTM standard). The diameter of the dolly used was $20 \mathrm{~mm}$. The greatest tensile pull-off force for which the coating could adhere to the substrate was evaluated in terms of mega Pascal. Breaking points occurred along the weakest plane of the whole structure. The adhesion strength $(X)$ was calculated in terms of MPa (Equation (1)).

$$
X=\frac{4 F}{\pi d^{2}}
$$

where $F$ is the rupture force (Newton), and $d$ is the diameter of the experiment cylinder (mm) (ASTM D4541-02).

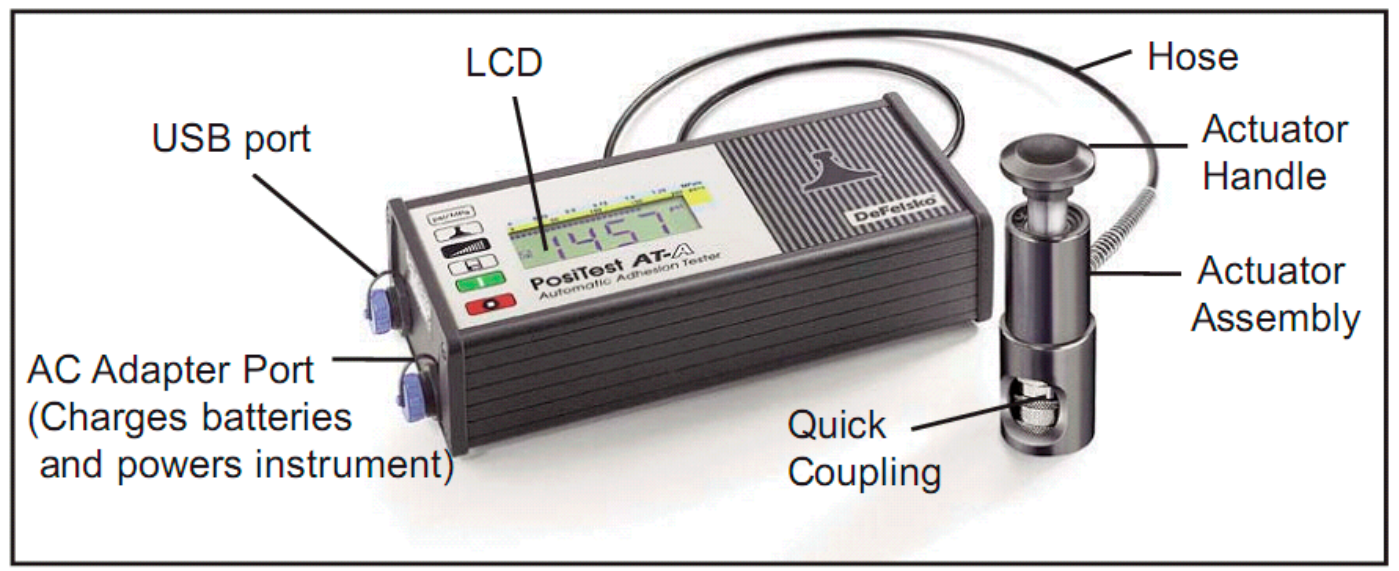

Figure 1. PosiTest ${ }^{\circledR}$ AT-A automatic pull-off adhesion tester.

The moisture content of the specimens was $8 \% \pm 0.5 \%$ when the pull-off adhesion tests were carried out, and the temperature was $25 \pm 3^{\circ} \mathrm{C}$. In order to have an estimate of the pull-off strength of the substrate material for comparison purposes, a set of specimens was also prepared without paints.

\subsection{Gas Permeability Measurement}

Many methods and apparatuses have been used and invented to measure permeability in solid woods and wood-composite materials as porous materials [1,26-29]. In the present study, longitudinal gas permeability was measured with an apparatus equipped with a 7-level electronic device; time measurement was carried out with millisecond precision [26,30,31]. Falling water was applied to measure and calculate the specific longitudinal gas permeability values. For each single specimen, gas permeability values were separately measured at seven different vacuum pressures. In every single run, the seven time measurements were carried out to finally calculate seven specific permeability values for each specimen. The glass tube had an internal diameter of $13 \mathrm{~mm}$. Water level was put to more than $15 \mathrm{~cm}$ above the first time measurement section (Gas 1). A fully airtight connection was made between the specimen and holder. The pressure difference $(\Delta P)$ was monitored by a pressure gauge connected to the permeability apparatus. The pressure difference could be read at any particular time and height. This provided monitoring of the viscose flow [22]; the gauge had a precision of millibar. Vacuum pressures at the starting and stopping levels were also measured [30].

Each specimen was tested three times to finally calculate the permeability. Then, the superficial permeability coefficient was calculated (Equations (2) and (3)) [32,33]. The superficial gas permeability coefficients $\left(k_{\mathrm{g}}\right)$ were corrected by the viscosity of air $\left(\mu=1.81 \times 10^{-5} \mathrm{~Pa}\right.$ s) for the calculation of the specific gas permeability $\left(K_{\mathrm{g}}=k_{\mathrm{g}} \mu\right)$. 


$$
\begin{gathered}
K_{\mathrm{g}}=\frac{V_{\mathrm{d}} C L\left(P_{\mathrm{atm}}-0.074 \bar{z}\right)}{t A(0.074 \bar{z})\left(P_{\mathrm{atm}}-0.037 \bar{z}\right)} \times \frac{0.760 \mathrm{mHg}}{1.013 \times 10^{6} \mathrm{~Pa}} \\
C=1+\frac{V_{\mathrm{r}}(0.074 \Delta z)}{V_{\mathrm{d}}\left(P_{\mathrm{atm}}-0.074 \bar{z}\right)}
\end{gathered}
$$

where:

$k_{\mathrm{g}}=$ superficial gas permeability $\left(\mathrm{m}^{3} \mathrm{~m}^{-1}\right)$;

$V_{\mathrm{d}}=\pi r^{2} \Delta z[r=$ radius of measuring tube $(\mathrm{m})]\left(\mathrm{m}^{3}\right)$;

$C=$ correction factor for gas expansion as a result of change in static head and viscosity of water;

$L=$ length of wood specimen $(\mathrm{m})$;

$P_{\text {atm }}=$ atmospheric pressure $(\mathrm{mHg})$;

$\bar{z}=$ average height of water over surface of reservoir during period of measurement (m);

$t=$ time (s);

$A=$ cross-sectional area of wood specimen $\left(\mathrm{m}^{2}\right)$;

$\Delta z=$ change in height of water during time $t(\mathrm{~m})$;

$V_{\mathrm{r}}=$ total volume of apparatus above point 1 (the volume of hoses was included) $\left(\mathrm{m}^{3}\right)$.

\subsection{Nanosilver Impregnation}

A 400 ppm aqueous nanosilver suspension was produced via the electrochemical technique in cooperation with Mehrabadi Mfg. Co. (Tehran, Iran). The nanoparticles ranged 30-80 nm in size; the $\mathrm{pH}$ was 6-7. Anionic and cationic surfactants were used to stabilize nanoparticles in the suspension. Specimens were impregnated using an empty-cell process in a pressure vessel. The pressure was set at 2.5 bars for $25 \mathrm{~min}$. Before conducting the tests on the specimens, they were kept for three months at room temperature.

The nanosuspension was prepared by transferring the silver metal ion from the aqueous phase to the organic phase, where it reacted with a monomer. The formation and size of the nanosilver was carefully monitored by transmission electron microscopy (TEM). Samples for TEM were prepared by drop-coating the Ag nanoparticle suspensions on to carbon-coated copper grids. Micrographs were obtained using an EM-900 ZEISS transmission electron microscope (Carl Zeiss AG, Jena, Germany). Two kinds of surfactants (anionic and cationic) were used in the suspension as stabilizer. The concentration of the surfactants was two times the nanosilver [34].

\subsection{Heat Treatment Process}

Specimens to be heat-treated were randomly placed in an oven. Heat treatment was carried out at atmospheric pressure and with normal air. The starting moisture content of specimens was $8 \% \pm 0.5 \%$. Heat treatment of each thermal modification temperature level was carried out in a single run. All HT and NS-HT specimens were heat-treated at $145{ }^{\circ} \mathrm{C}$ for $12 \mathrm{~h}$. Heat treatment for the HT-145 and NS-HT-145 specimens was discontinued. Then, HT-165 and NS-HT-165, as well as HT-185 and NS-HT-185 specimens continued to be heated at 165 and $185^{\circ} \mathrm{C}$ for four more hours, respectively. During the heat treatment process, no specimen was in touch with the metal parts of the oven, to prevent extra overheating at one spot. Once the heat treatment process was completed, the silicone adhesive around all specimens was checked to make sure there was no failure in them. The gas permeability was then measured.

\subsection{SEM Imaging}

Scanning electron microscope (SEM) imaging was carried out at a thin-film laboratory, FE-SEM lab (Field Emission), School of Electrical and Computer Engineering, the University of Tehran. A field-emission cathode in the electron gun of a scanning electron microscope provides narrower probing beams at low as well as high electron energies. This way, the spatial resolution was improved 
and the charging and damage to the specimens were minimized. As wood is a nonconductive material, a gold sputtering thickness of 6-8 $\mathrm{nm}$ was applied on the surface of specimens prior to SEM imaging.

\subsection{Statistical Analysis}

One-way analysis of variance (ANOVA) was carried out to discern significant difference at $95 \%$ level of confidence, using the SAS software program (version 9.2) (2010). Grouping was then made between treatments using Duncan's multiple range test. Regression analyses, including dendrogram and using Ward methods with squared Euclidean distance intervals, were carried out by SPSS/18 (2010). For the regression analysis, a $p$-value of less than $5 \%(<0.05)$ was determined as the significance level. Based on the $p$-value, the critical $R$ value was 0.63 . Fitted-line and scatter plots were made using Minitab software (version 16.2.2) (2010).

\section{Results}

The amount of nanosilver suspension absorption after the impregnation process was measured to be $0.38 \mathrm{~g} / \mathrm{cm}^{3}$. Results of the permeability tests showed that the lowest specific gas permeability was observed in specimens before NS-impregnation or heat treatment (NS-HT-165 treatment, $6.898 \times 10^{-13} \mathrm{~m}^{3} \mathrm{~m}^{-1}$ ), and the highest was found in NS-HT-185 after NS-impregnation $\left(15.576 \times 10^{-13} \mathrm{~m}^{3} \mathrm{~m}^{-1}\right)$.

In the un-impregnated specimens, heat treatment slightly increased the specific gas permeability values in all three temperatures of 145,165 , and $185^{\circ} \mathrm{C}$, but the increase was not statistically significant (Figure 2). The highest increase in the un-impregnated specimens was observed in HT-145 treatment (only 5.3\%). As for the nanosilver-impregnated specimens (the right columns of Figure 2), impregnation with the nanosuspension significantly increased the permeability in all treatment (Figure 2). In some cases, the amount of increase was more than $107.5 \%$. The highest specific gas permeability was found in the NS-HT-185 treatment after the NS-impregnation and before the heat treatment. The increasing effect of heat treatment on permeability was significantly intensified by the thermal conductivity of silver nanoparticles; the highest increase caused by heat treatment of NS-impregnated specimens was seen in NS-HT-145 treatment (20.8\%). The only treatment showing a decreasing trend in permeability caused by heat treatment was NS-HT-185. This treatment showed a decrease of about $8.8 \%$.

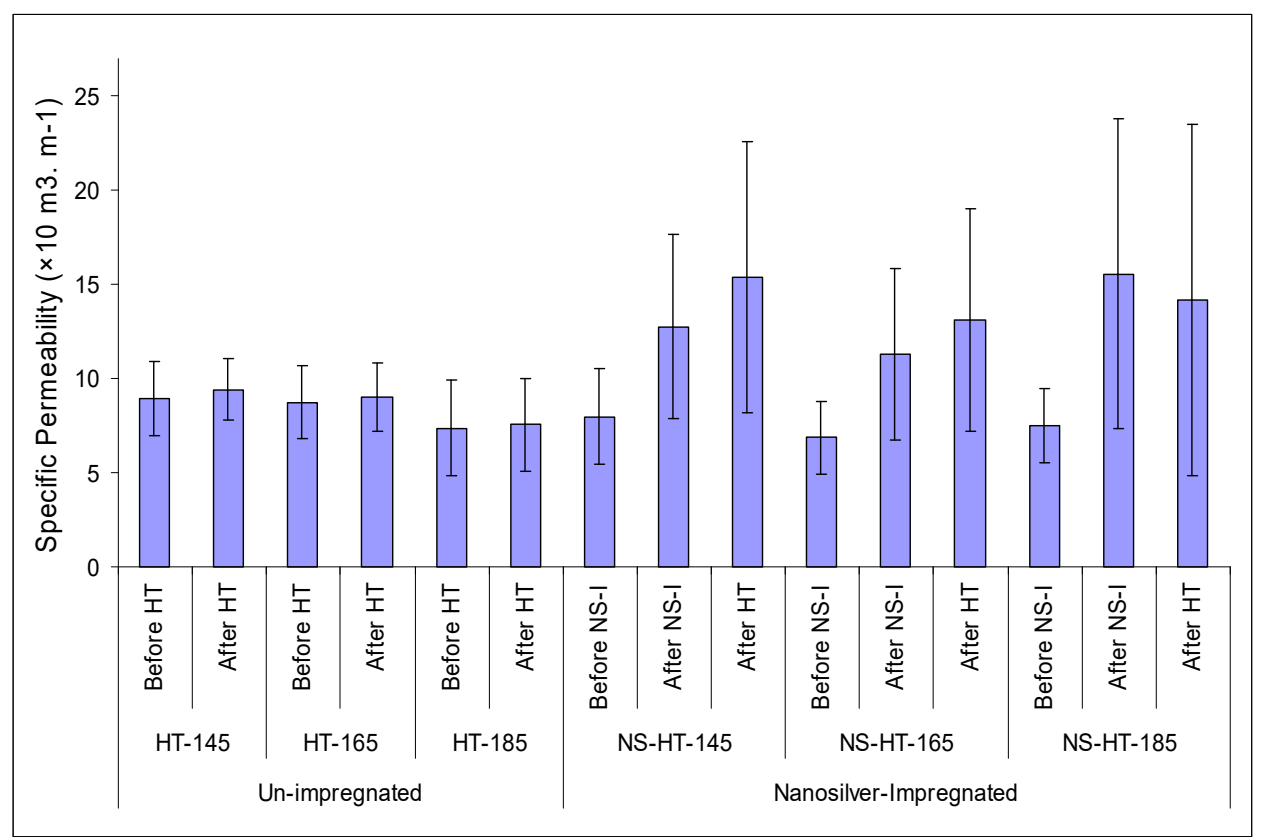

Figure 2. Specific longitudinal gas permeability in the beech specimens $\left(\times 10^{-13} \mathrm{~m}^{3} \mathrm{~m}^{-1}\right)$ (error bars indicate the standard deviation for each column). 
The maximum pull-off adhesion strength was observed in the control specimens (un-impregnated and un-heated) painted with polyester ( $8.98 \mathrm{MPa})$, and the lowest pull-off strength was found in the un-painted and un-heated specimens that were NS-impregnated (3.10 MPa) (Figure 3). NS-impregnation generally increased pull-off strength in the heat-treated painted specimens. In the unpainted specimens, however, a reverse trend was observed.

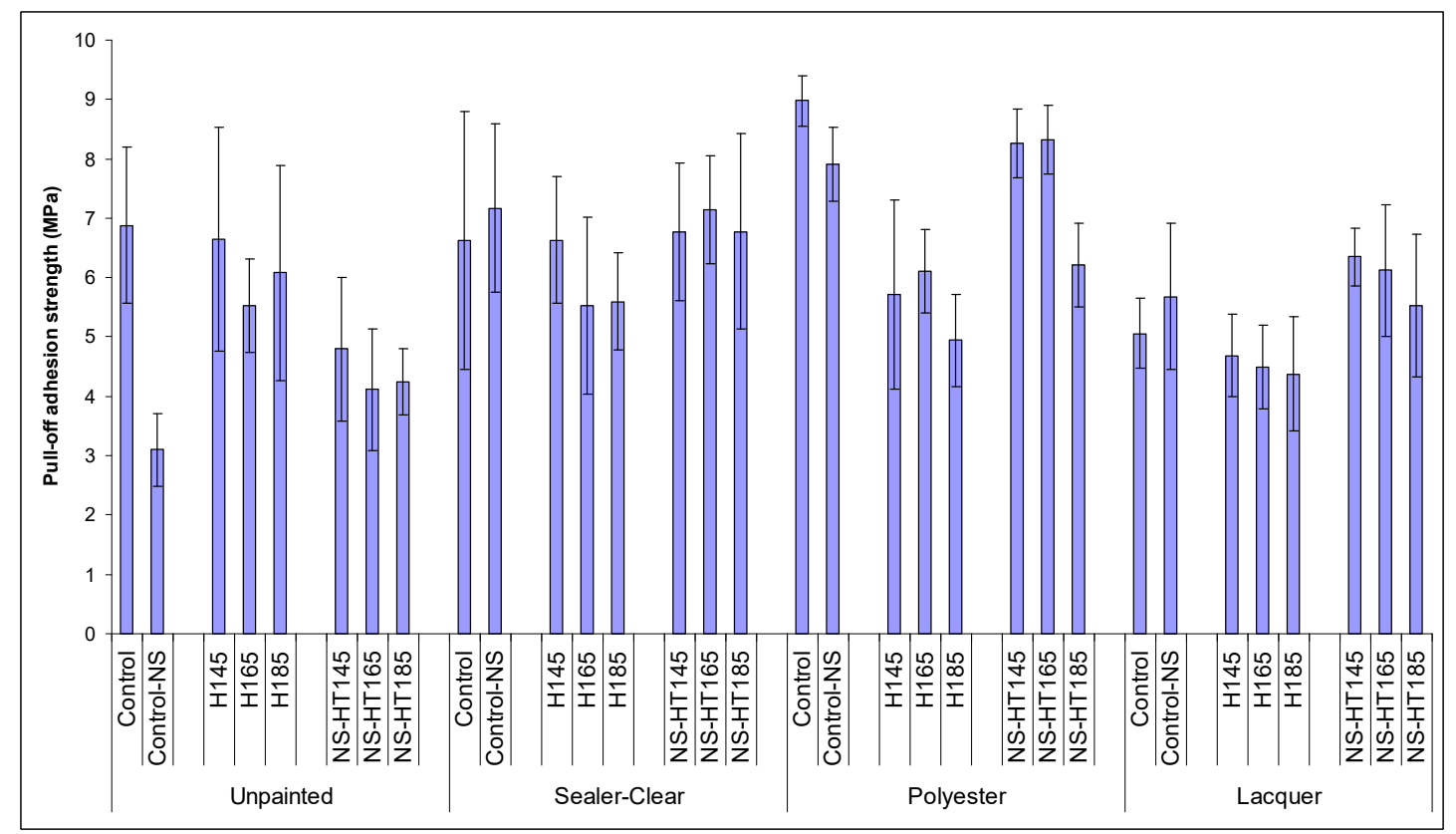

Figure 3. Pull-off adhesion strength (MPa) of different treatments of beech specimens (error bars indicate the standard deviation for each column).

\section{Discussion}

Heat treatment made the specimens lose their moisture content completely, resulting in the vessel perforations and pit openings to shrink and be wide open. This shrinkage led to increased specific air permeability, because permeability is influenced by the porous structure of the material, and even slight changes in the porous system may significantly affect permeability $[35,36]$. The shrinkage is partially permanent due to the irreversible hydrogen bonding that occurs when water is moved in the cell wall $[8,21]$.

NS-impregnation also resulted in significant increases of permeability in all NS-impregnated treatments. This increase was attributed to the high pressure applied in the pressure vessel, resulting in the rupture of vessel perforations, tyloses, and any other physical obstacle in the way of fluid transfer. SEM images showed vessels that were blocked (Figure 4A). The blockage was ruptured and torn open after NS-impregnation (Figure 4B,C). Therefore, fluid could flow more easily, and eventually, permeability increased significantly.

Heat treatment decreased pull-off strength in all three coatings studied here (Figure 3). It is reported that heat treatment results in the occurrence of microcracks in the wood structure and thermal degradation of cell wall polymers [5,37-39]. These microcracks led to unwanted penetration of adhesive film into wood texture, far from being involved in the process of anchoring and sticking dolly to wood substrate. However, in the NS-impregnated specimens, heat was transferred to deeper parts of specimens, and therefore, accumulation of heat did not occur on the surface of specimens, eventually decreasing microcracks in NS-impregnated specimens. This was translated into higher pull-off strength in NS-impregnated specimens of all three types of coatings. 


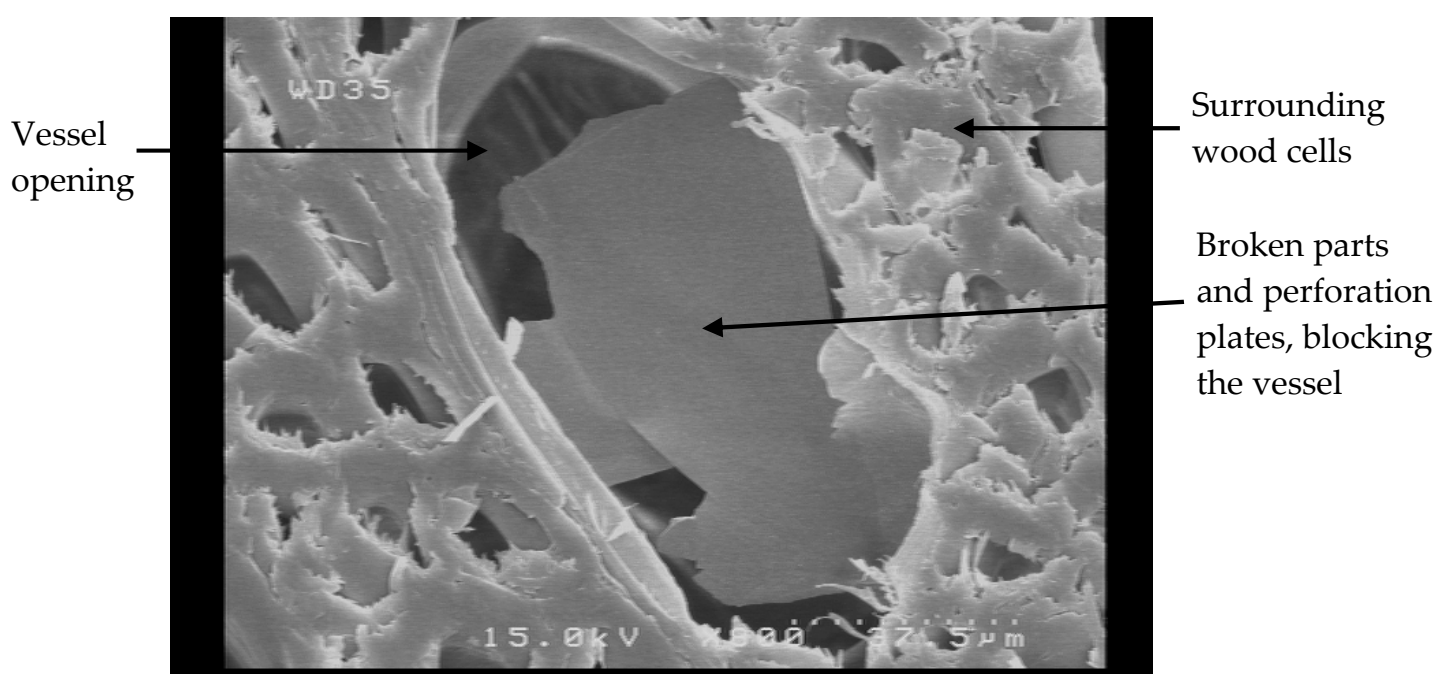

(A)

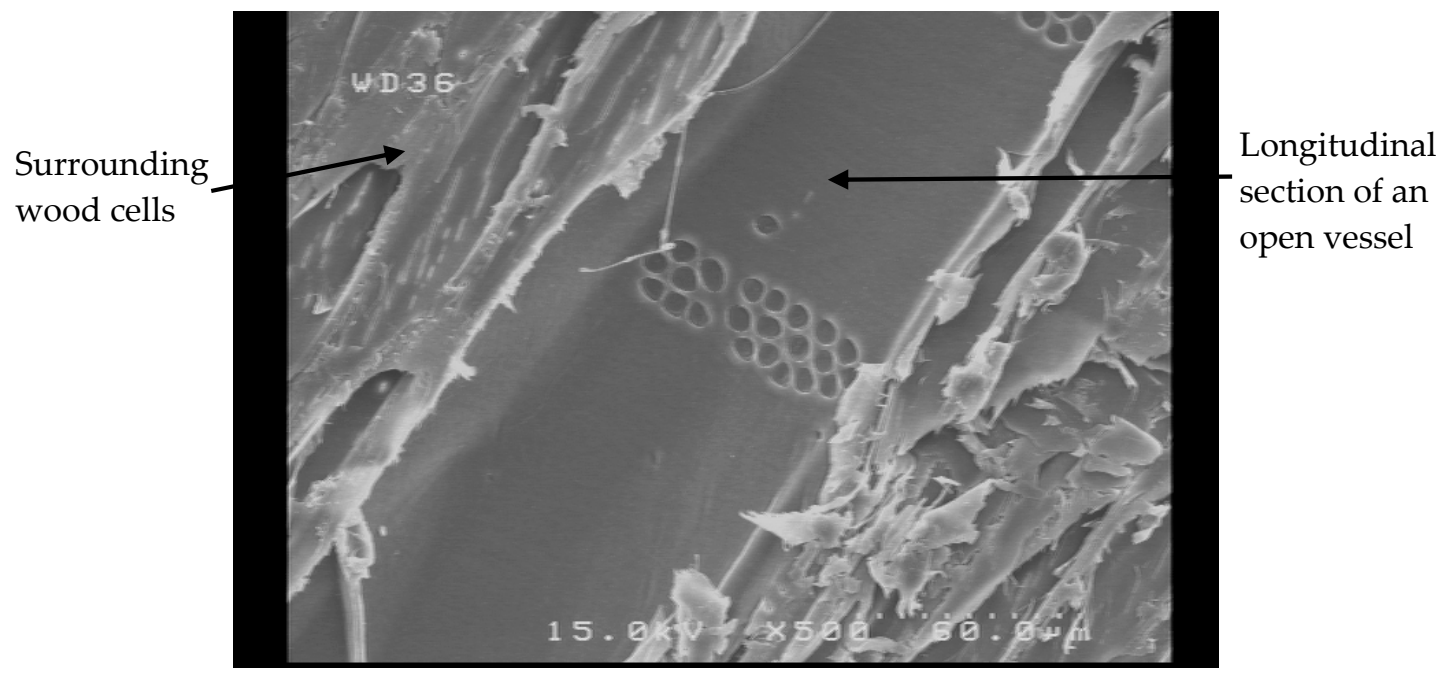

(B)

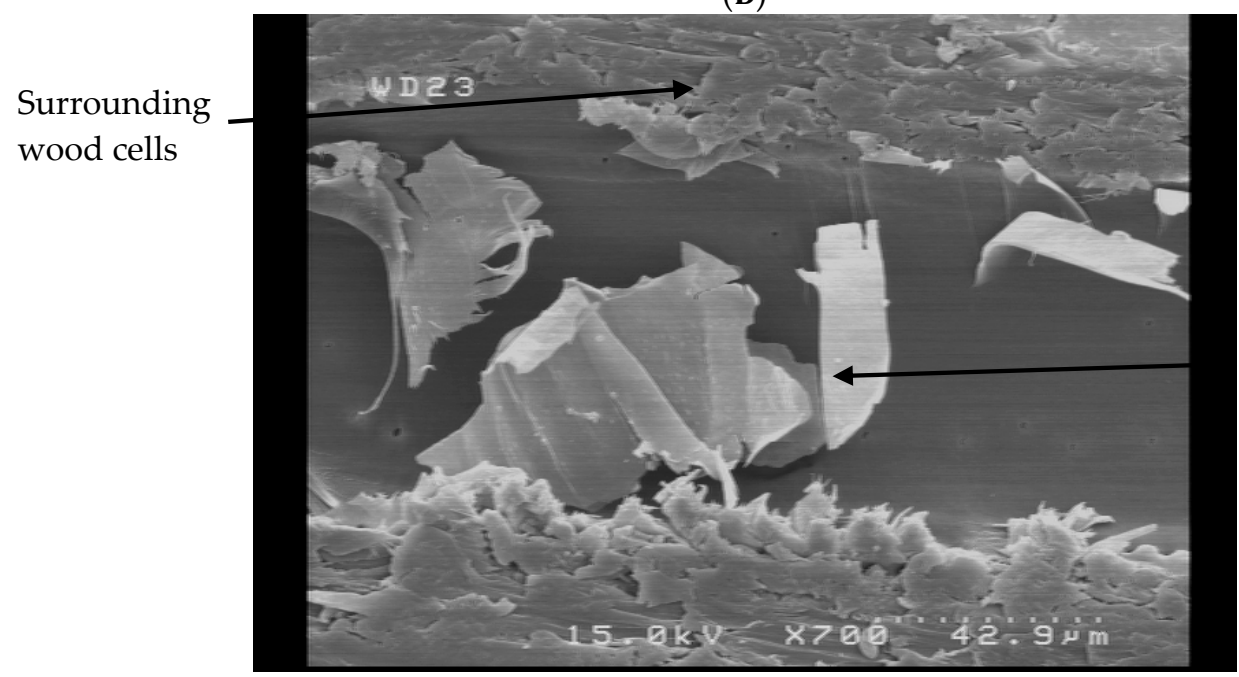

Longitudinal section of a blocked vessel by broken cell parts and perforation plates

(C)

Figure 4. SEM images showing cell parts and perforation plates $(\downarrow)$; (A) cross-section of a blocked vessel by distorted and ruptured vessel elements; (B) longitudinal section of an open vessel; (C) longitudinal section of a vessel blocked by broken cell parts and perforation plates. 
The fitted-line plot between pull-off adhesion strength versus specific air permeability in all treatments showed no particular trend between these two properties (Figure 5). Regression analysis also showed insignificant $R^{2}$ between air permeability versus pull-off strength in almost all specimens and treatments (Table 1). The only significant $R^{2}$ was found in HT-145 polyester specimens. However, this one case cannot be a reliable indicator as to the existence of potentially significant $R^{2}$ between the two properties of permeability and pull-off strength. Therefore, it can be concluded that air permeability cannot be considered a good criterion to estimate the pull-off strength in beech wood. Both properties (permeability and pull-off strength) are dependent on the porous structure of materials, but permeability is influenced by the continuous pores while pull-off strength is more dependent on the surface pores, whether continuous or isolated. That is, an isolated and blocked vessel can also be active in the penetration and anchoring of adhesive, similar to a continuous vessel (Figure 4A). However, permeability is only dependent on the number of continuous vessels and pores, their attributes, and the way they are connected to one another.

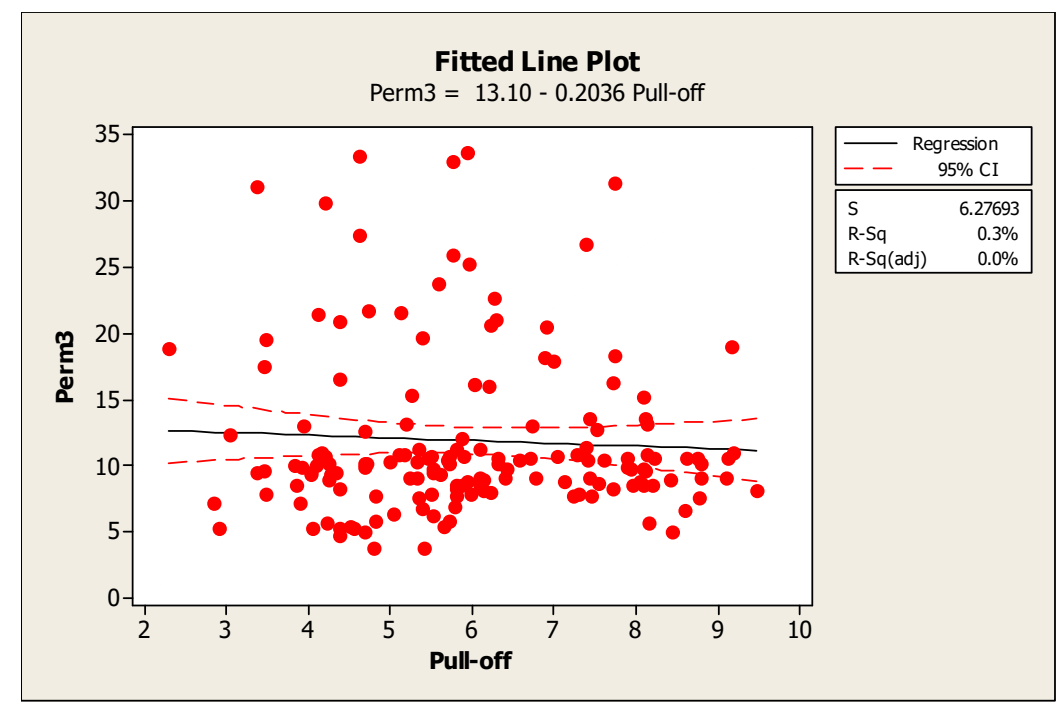

Figure 5. Fitted-line plot between pull-off adhesion strength versus specific air permeability (Perm3 = specific air permeability measured at the third vacuum pressure or water column level).

Table 1. Regression analysis between longitudinal specific air permeability versus pull-off adhesion strength in different treatments.

\begin{tabular}{|c|c|c|c|c|c|}
\hline \multirow{2}{*}{\multicolumn{2}{|c|}{ Treatments }} & \multicolumn{4}{|c|}{$R$-Square } \\
\hline & & Un-Painted & SC & Lacquer & Polyester \\
\hline \multirow{3}{*}{ Un-heated } & Control & $\begin{array}{l}0.795 \\
\text { ns(-) }\end{array}$ & $\begin{array}{l}0.191 \\
\mathrm{~ns}(+)\end{array}$ & $\begin{array}{l}0.047 \\
\mathrm{~ns}(+)\end{array}$ & $\begin{array}{l}0.732 \\
\mathrm{~ns}(+)\end{array}$ \\
\hline & \multirow{2}{*}{ NS-I } & 0.304 & 0.519 & 0.443 & 0.200 \\
\hline & & $\mathrm{ns}(-)$ & $\mathrm{ns}(+)$ & $\mathrm{ns}(+)$ & $\mathrm{ns}(+)$ \\
\hline \multirow{4}{*}{ HT-145 } & \multirow{2}{*}{ Control } & 0.004 & 0.683 & 0.503 & 0.954 \\
\hline & & $\mathrm{ns}(-)$ & $\mathrm{ns}(+)$ & ns(-) & ${ }^{*}(-)$ \\
\hline & \multirow{2}{*}{ NS-I } & 0.004 & 0.061 & 0.034 & 0.186 \\
\hline & & $\mathrm{ns}(-)$ & $\mathrm{ns}(+)$ & $\mathrm{ns}(-)$ & $\mathrm{ns}(-)$ \\
\hline \multirow{4}{*}{ HT-165 } & \multirow{2}{*}{ Control } & 0.111 & 0.470 & 0.105 & 0.676 \\
\hline & & $\mathrm{ns}(-)$ & $\mathrm{ns}(+)$ & $\mathrm{ns}(+)$ & $\mathrm{ns}(+)$ \\
\hline & \multirow{2}{*}{ NS-I } & 0.469 & 0.135 & 0.650 & 0.284 \\
\hline & & $\mathrm{ns}(-)$ & $\mathrm{ns}(+)$ & $\mathrm{ns}(-)$ & $\mathrm{ns}(-)$ \\
\hline \multirow{4}{*}{ HT-185 } & \multirow{2}{*}{ Control } & 0.240 & 0.638 & 0.234 & 0.438 \\
\hline & & $\mathrm{ns}(+)$ & $\mathrm{ns}(+)$ & $\mathrm{ns}(+)$ & $\mathrm{ns}(+)$ \\
\hline & \multirow{2}{*}{ NS-I } & 0.551 & 0.520 & 0.246 & 0.481 \\
\hline & & $\mathrm{ns}(+)$ & ns(-) & ns(-) & $\mathrm{ns}(+)$ \\
\hline
\end{tabular}

SC = sealer-clear painted; NS-I = nanosilver-impregnated; $\mathrm{ns}$ = nonsignificant; HT = heat-treated. 


\section{Conclusions}

- Impregnating beech wood with nanosilver suspension results in the rupture of perforation plated and pit openings, and eventually permeability increases significantly.

- Higher permeability causes more adhesive being penetrated deep in to the pores of the wood substrate, being left out of the sticking process, eventually decreasing pull-off strength.

- Permeability depends on the continuous pore system. Pull-off adhesion strength, however, is dependent on the surface pore system of the wood substrate. Therefore, there is no significant correlation between pull-off adhesion strength versus air permeability.

Author Contributions: Methodology, H.T. and A.E.; Validation, H.T.; Investigation, H.T. and A.E; Writing-Original Draft Preparation, H.T., A.E. and A.P.; Writing-Review \& Editing, H.T., A.E. and A.P.; Visualization, H.T. and A.E; Supervision, H.T and A.P.

Funding: This research received no external funding.

Acknowledgments: Authors are grateful to Jack Norton (Retired, Horticulture \& Forestry Science, Queensland Department of Agriculture, Forestry and Fisheries, Australia) for his constant scientific support and inspiration, as well as Alexander von Humboldt Stiftung, Germany.

Conflicts of Interest: The authors declare no conflict of interest.

\section{References}

1. Siau, J.F. Flow in Wood; Syracuse University Press: Syracuse, NY, USA, 1971.

2. Siau, J.F. Wood: Influence of Moisture on Physical Properties; Blacksburg, V.A., Ed.; Department of Wood Science and Forest Products, Virginian Polytechnic Institute and State University: Blacksburg, VA, USA, 1995.

3. Siau, J.F. Transport Processes in Wood; Springer: Berlin/Heidelbergh, Germany; GmbH \& Co. KG: Berlin, Germany, 2011.

4. Skaar, C. Wood-Water Relations; Springer: Berlin/Heidelberg, Germany, 1988.

5. Oltean, L.; Teischinger, A.; Hansmann, C. Influence of temperature on cracking and mechanical properties of wood during wood drying-A review. BioResources 2008, 2, 789-811.

6. Mosqueda, M.R.P.; Tabil, L.G.; Christensen, C. Effect of drying conditions and level of condensed distillers solubles on protein quality of what distillers dried grain with solubles. Dry. Technol. 2013, 31, 811-824. [CrossRef]

7. Fernandez-Puratich, H.; Oliver-Villanueva, J.V. Quantification of biomass and energetic value of young natural regenerated stands of Quercus ilex under Mediterranean conditions. Bosque 2014, 35, 65-74.

8. Borrega, M.; Karenlampi, P.P. Hygroscopicity of heat-treated norway spruce (Picea abies) wood. Eur. J. Wood Wood Prod. 2010, 68, 233-235. [CrossRef]

9. Hering, S.; Keunecke, D.; Niemz, P. Moisture-dependent orthotropic elasticity of beech wood. Wood Sci. Technol. 2012, 46, 927-938. [CrossRef]

10. Barna, M. Natural regeneration of Fagus sylvatica L.: A Review. Austrian J. For. Sci. 2011, 128, 71-91.

11. Hill, C. Wood Modification Chemical, Thermal and Other Processes; John Wiley \& Sons, Ltd.: Hoboken, NJ, USA, 2006.

12. Schmidt, O. Wood and Tree Fungi: Biology, Damage, Protection, and Use; Springer: Berlin/Heidelberg, Germany, 2006.

13. Maresi, G.; Oliveira Longa, C.M.; Turchetti, T. Brown rot on nuts of Castanea sativa Mill: An emerging disease and its causal agent. iForest Biogeosci. For. 2013, 6, 294-301. [CrossRef]

14. Awoyemi, L. Determination of optimum borate concentration for alleviating strength loss during heat treatment of wood. Wood Sci. Technol. 2007, 42, 39-45. [CrossRef]

15. Repellin, V.; Guyonnet, R. Evaluation of heat treated wood swelling by differential scanning calorimetry in relation with chemical composition. Holzforschung 2005, 59, 28-34. [CrossRef]

16. Pati, R. Molecule for electronics: A myriad of opportunities comes with daunting challenges. J. Nanomater. Mol. Nanotechnol. 2012, 1. [CrossRef]

17. Sadeghi, B.; Rastgo, S. Study of the shape controlling silver nanoplates by reduction process. Int. J. Bio-Inorg. Hybrid Nanomater. 2012, 1, 33-36. 
18. Saber, R.; Shakoori, Z.; Sarkar, S.; Tavoosidana, G.; Kharrazi, S.; Gill, P. Spectroscopic and microscopic analyses of rod-shaped gold nanoparticles interacting with single-stranded DNA oligonucleotides. IET Nanobiotechnol. 2013, 7, 42-49. [CrossRef] [PubMed]

19. Tomic, S.L.; Micic, M.M.; Dokic, D.; Vasiljevic-Radvic, D.G.; Filipovic, J.M.; Suljovrujic, E.H. Preparation of silver (I) complexes with itaconic acid-based hydrogels for biomedical application. Mater. Manuf. Process. 2009, 24, 1197. [CrossRef]

20. Nguyen, N.T.; Nguyen, B.H.; Ba, D.T.; Pham, D.G.; Khai, T.V.; Nguyen, L.T.; Tran, L.D. Microwave-assisted synthesis of silver nanoparticles using chitosan: A novel approach. Mater. Manuf. Process. 2014, 29, 418. [CrossRef]

21. Taghiyari, H.R.; Enayati, A.; Gholamiyan, H. Effects of nano-silver impregnation on brittleness, physical and mechanical properties of heat-treated hardwoods. Wood Sci. Technol. 2013, 47, 467-480. [CrossRef]

22. Taghiyari, H.R. Effects of heat-treatment on permeability of untreated and nanosilver-impregnated native hardwoods. Maderas Cienc. Y Tecnol. 2013, 15, 183-194. [CrossRef]

23. Sönmez, A.; Budakci, M.; Huseyin, P. The effect of the moisture content of wood on the layer performance of water-borne varnishes. BioResources 2011, 6, 3166-3178.

24. Figueroa, M.; Bustos, C.; Dechent, P.; Reyes, L.; Cloutier, A.; Giuliano, M. Analysis of rheological and thermo-hygro-mechanical behaviour of stress-laminated timber bridge deck in variable environmental conditions. Maderas Cienc. Y Tecnol. 2012, 14, 303-319.

25. ASTM D 4541-02. Standard Test Method for Pull-Off Strength of Coatings Using Portable Adhesion Testers; ASTM: West Conshohocken, PA, USA, 2006.

26. Taghiyari, H.R.; Kalantari, A.; Avramidis, S. Effect of wollastonite nanofibers and exposure to Aspergillus niger fungus on air flow rate in paper. Measurement 2019, 136, 307-313. [CrossRef]

27. Shi, S.H.Q. Diffusion model based on Fick's second law for the moisture absorption process in wood fiber-based composites: Is it suitable or not? Wood Sci. Technol. 2007, 41, 645-658. [CrossRef]

28. Dermoe, D.; Zillig, W.; Carmeliet, J. Variation of measured cross-sectional cell dimensions and calculated water vapor permeability across a single growth ring of spruce wood. Wood Sci. Technol. 2012, 46, 827-840. [CrossRef]

29. Shibata, H.; Hirohashi, Y. Effect of segment scale in a pore network of porous materials on drying periods. Dry. Technol. 2013, 31, 743-751. [CrossRef]

30. Ghorbani, M.; Akhtari, M.; Taghiyari, H.R.; Kalantari, A. Effects of silver and zinc-oxide nanoparticles on gas and liquid permeability of heat-treated Paulownia wood. Austrian J. For. Sci. 2012, 129, 106-123.

31. Esmailpour, A.; Taghiyari, H.R.; Golchin, M.; Avramidis, S. On the fluid permeability of heat treated paulownia wood. Int. Wood Prod. J. 2019, 10, 55-63. [CrossRef]

32. Hernandez, V.; Avramidis, S.; Navarrete, J. Albino strains of Ophiostoma spp. Fungi effect on radiate pine permeability. Eur. J. Wood Wood Prod. 2012, 70, 551-556. [CrossRef]

33. Choo, A.C.Y.; Tahir, M.P.; Karimi, A.; Bakar, E.S.; Abdan, K.; Ibrahim, A.; Balkis, F.A.B. Study on the longitudinal permeability of oil palm wood. Ind. Eng. Chem. Res. 2013, 52, 9405-9410. [CrossRef]

34. Taghiyari, H.R.; Norton, J. Effect of silver nanoparticles on hardness in medium-density fiberboard (MDF). J. iForest Biogeosci. For. 2014, 8, 677-680. [CrossRef]

35. Dashti, H.; Shahverdi, M.; Taghiyari, H.R.; Salehpur, S.; Heshmati, S. Effects of steaming and microwave pretreatments on mass transfer characteristics of Aleppe oak (Quercus infectoria). BioResources 2012, 7, 3262-3273.

36. Taghiyari, H.R. Correlation between gas and liquid permeability in some nanosilver-impregnated and untreated hardwood. J. Trop. For. Sci. 2012, 24, 249-255.

37. Korkut, S.; Budakci, M. Effect of high-temperature treatment on the mechanical properties of Rowan (Sorbus aucuparia L.) wood. Dry. Technol. 2009, 27, 1240-1247. [CrossRef]

38. Bayani, S.; Taghiyari, H.R.; Papadopoulos, A.N. Physical and mechanical properties of thermally-modified beech wood impregnated with silver nano-suspension and their relationship with the crystallinity of cellulose. Polymers 2019, 11, 1538. [CrossRef] [PubMed]

39. Bayani, S.; Bazyar, B.; Mirshokraie, S.A.; Taghiyari, H.R. Effects of heat treatment on the relative amounts of cellulose in nanosilver-impregnated and untreated poplar wood (Populus alba). Floresta E Ambiente 2019, 26, e20160398. [CrossRef] 